\title{
ABAJUR COR DE CARNE - CARTOGRAFIA PELA DANÇA: POSSÍVEIS EPISTEMOLOGIAS DE UMA ARTE NEGRO-BRASILEIRA
}

\author{
Maicom Souza e Silva \\ Elaine Augusta da Silva Vieira
}

\begin{abstract}
Resumo: Abajur Cor de Carne - Cartografia pela Dança: possíveis epistemologias de uma arte negro-brasileira é uma análise do espetáculo de dança contemporânea, homônimo, montado pelo Coletivo Emaranhado na cidade de Vitória/ES em 2019. Sinalizamos, a partir do batucar-cantar-dançar, as performances dos artistas que restauram os comportamentos do povo negro-brasileiro. O caminho metodológico seguido, por este artigo, foi o estudo de caso pautado na observação de vídeo e registros de imagens do espetáculo, acompanhado da revisão bibliográfica das obras que contemplam a concepção de corpo, performance, práticas performativas e etnocenologia na perspectiva de Amanda Braga (2015), Achille Mbembe (2018), Cesar Huapaya (2017), Nadir Nóbrega (2008) e Zeca Ligiéro (2011). O propósito da pesquisa limita-se em identificar e compreender as construções dramatúrgicas e gestuais que expressam, em situação performativa, o corpo artístico e suas condições estéticas dentro de uma premissa afro-brasileira. Nesse sentido, o espetáculo é uma proposta em favor das mulheres, principalmente as mulheres negras. O corpo artístico é um signo do saber, produzido e memorizado na relação ontológica do cotidiano negro afrodiaspórico. Os textos cênicos, as músicas, os jogos de linguagem com os fenótipos e o protagonismo das mulheres pretas em cena promovem e reivindicam os direitos da população negra.
\end{abstract}

Palavras-chaves: Arte Cênica; Corpo; Performance.

Abstract: Abajur cor de carne - Cartografia pela dança: possíveis epistemologias de uma arte negro-brasileira is an analysis of the contemporary dance performance, homonymous, assembled by Coletivo Emaranhado in the city of Vitória/ES in 2019. Considering the batucarcantar-dançar, we signaled the performances of artists who restore the behavior of Afrobrazilian people. We applied case study methodology, based on the observation of video and records images of the show, accompanied by a bibliographic review of the works, which include body design, performance, performative practices and ethnocenology from the perspective of Amanda Braga (2015), Achille Mbembe (2018), Cesar Huapaya (2017), Nadir Nóbrega (2008) and Zeca Ligiéro (2011). The purpose of the research is limited in identifying and understanding the dramaturgical and gestural constructions they express, in a performative situation, the artist's body and its aesthetic conditions within a Afro-brazilian premise. The show is a proposal in favor of women, mainly black women. The artist's body is a sign of knowledge, produced and memorized in the ontological relationship of the black aphrodiasporic everyday. The scenic texts, the songs, the language game with the phenotypes and the role of black women on stage promote and claim the rights of people of African descent.

Keywords: Scenic Art; Body; Performance.

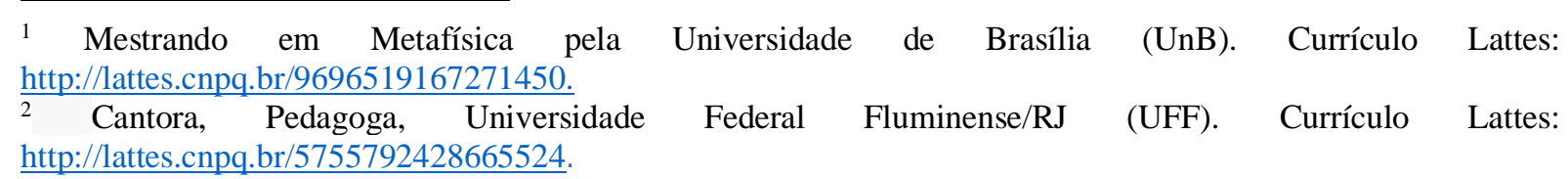




\section{Apresentação}

Este trabalho tenciona analisar o espetáculo de dança Abajur Cor de Carne, montado pelo Coletivo Emaranhado, na cidade de Vitória/ES, em 2019. A linguagem da dança contemporânea pesquisada apresenta, no corpo artístico, resíduos de identidade que representam e restauram o comportamento das mulheres atuais que sofrem violação de direitos, conduzindo-nos para uma reflexão sobre as múltiplas formas de violência que abatem os seus corpos, principalmente sobre aqueles que carregam além do signo de gênero, o da raça.

A dramaturgia da obra situa-se no âmbito da dança, tomando como dispositivo a vivência da mulher brasileira, porém, numa tentativa de evidenciar o gestus, hábitos e crenças das comunidades afro-brasileiras. Desse modo, apresentaremos alguns signos que exprimem a corporeidade negro-brasileira nas artes.

O caminho metodológico seguido, por este artigo, foi o estudo de caso, pautado na observação de vídeo e registro de imagens do espetáculo, acompanhado da revisão bibliográfica das obras que contemplam a concepção de arte, corpo, performance, práticas performativas e etnocenologia, nas perspectivas de Amanda Braga (2015), Achille Mbembe (2018), Cesar Huapaya (2017), Nadir Nóbrega (2008) e Zeca Ligiéro (2011). O propósito da pesquisa limitase em identificar e compreender qual foi a construção dramatúrgica e a gestualidade para expressar, em situação performativa, o corpo artístico e suas condições de ação estética dentro de uma premissa afro-brasileira, não buscando esgotar, aqui, as questões de gênero, raça e os dramas sociais que envolvem a violência contra a mulher negra.

Com base nos estudos de etnocenologia, pesquisamos como o Coletivo Emaranhado reconhece o engajamento artístico em cena, enquanto possibilidade corporal (corpo-existênciaação-performance) para registrar a forma de vida - a bios, a imagem, o gestus social, o habitus e os dispositivos pulsionais da encenação. Assim, descrevemos o corpo em ação do Outro ${ }^{3}$ como sujeito - seus gestos em cena, posturas, movimentos, sons, figurinos, textos cênicos, suas reações físicas e expressões faciais; em seguida, descrita para registro, o gestual estético da arte afro-brasileira.

\footnotetext{
${ }^{3}$ A filosofia da libertação de Dussel alimenta-se na relação concreta de respeito e alteridade com o outro, no olhar e na relação de responsabilidade mútua. Nesta filosofia, a premissa é de que as relações pessoais estabeleçam uma cultura de respeito ao Outro em sua totalidade, seja quem for (as relações pessoais passam a ter outro significado). Uma relação concreta se faz apenas na alteridade, seu principal meio de expressão está na relação rosto a rosto, no olhar. A filosofia da libertação é um processo de abertura para o Outro, diferente do que ocorre na superação da dialética da dominação. Dussel chama esta abertura de analética, método da filosofia da libertação que se opõe à dialética dominadora (DUSSEL, 1977, p. 163).
} 


\section{Arte negra, corpo negro}

O artigo percorre a presença de manifestações negro-brasileiras no espetáculo de dança contemporânea Abajur Cor de Carne - Cartografia pela Dança: possíveis epistemologias de uma arte negro-brasileira, cuja apresentação se deu na cidade de Vitória/ES, no Centro Cultural SESC Glória em março de 2020. Tomamos como dispositivo, para investigação, a tríade proposta por Zeca Ligiéro (2011), o batucar-cantar-dançar, um léxico de gestos articulados com ritmos e cantos, que através do corpo informam um código estilístico para estudar a arte negra.

O espetáculo possui duração de sessenta 60 minutos. Após assistir o trabalho, escolhemos algumas fotografias para elaborar uma descrição das cenas, com base na tríade proposta por Ligiéro, na tentativa de identificar as pesquisas estéticas de corpo negro-brasileiro cênico. Salientamos que o projeto não é uma análise cronológica de todas as propostas corporais expressas no espetáculo, mas apenas a identificação dos perceptos e afectos que acreditamos estarem enraizados na ancestralidade africano-brasileira - impressões que estão entrelaçadas em nossa subjetividade enquanto espectador e pesquisador.

O texto cênico, os cantos, a trilha e o modo como os performers utilizaram o corpo em cena foram observados, bem como foi feito também um estudo, sobre o qual lançaremos nosso olhar, a fim de identificar uma epistemologia inserida nas manifestações negro-brasileiras, confirmando, assim, que as tratamos como um objeto composto, ou seja, amarrado pela dança, música e canto.

Quando alguém está tocando um atabaque ou qualquer outro instrumento, uma linguagem espiritual está sendo articulada. O canto é percebido como a interpretação dessas linguagens para a comunidade presente no aqui e agora. Dançar seria a 'aceitação das mensagens espirituais propagadas' através de nosso próprio corpo, bem como o encontro dos membros nas celebrações conjuntas, sob o perfeito equilíbrio (Kinenga) da vida (LIGIÉRO, 2011, p. 135).

O povo africano que aportava no Brasil por volta do século XVI até a segunda metade do século XIX compunham as mais variadas etnias, sendo a grande maioria de origem banto, habitantes do Centro Oeste da África negra, cujos domínios passavam por Angola, Gabão, República de Camarões e Matamba, chegando a Oeste de Moçambique e ao Norte da África do Sul. No século XVII, chegam ao Porto de Salvador e de Recife os sudaneses, trazendo suas práticas culturais denominadas de comunidade Jeje e Iorubá, que juntas apresentaram suas divindades, voduns e orixás. No século XIX, o Brasil já era um território com grande 
concentração das diversas etnias africanas, sendo-lhes uma característica bastante comum: a soltura com que moviam seus corpos ao som de palmas, cantos e tambores (LIGIÉRO, 2011).

[...] uma apresentação como o candomblé possui vários dispositivos de tecidos performativos dos grupos sociais que vieram da África. Ele mostra seu habitus e singularização na forma de cantar, dançar e descrever seus rituais. Essas partituras orgânicas e pulsionais são marginalizadas e reprimidas pela sociedade, que não aceitam seus habitus e gestus como cidadãos. As técnicas de corpo trazidas para o Brasil pelos africanos e desenvolvidas pelos brasileiros engendraram várias corporeidades e modos de subjetividades originais na escritura social de uma nova civilização no Brasil. A sociedade branca, desde a escravidão até hoje, rejeita esse corpo afro em favor da corporeidade ariana de estilo barroco e branco (HUAPAYA, 2019, p. 40).

A circularidade, o canto coral, o movimento do corpo utilizando todas as articulações ósseas, principalmente as do tronco, uma vibração na qual ocupa múltiplas direções - pulos, giros, contratempos, vibrações assimétricas dos membros - caracterizavam as manifestações desses corpos pretos. Os africanos da diáspora, quando aportavam em solo brasileiro, eram corpos psicofísicos que interagiam com outros performers com palmas e diálogos em seu idioma nativo. A linguagem da dança, gravada nesses corpos do Brasil colonial, era uma atitude de resistência desses povos escravizados, que aguardavam em confinamento nos portos antes de serem separados uns dos outros (LIGIÉRO, 2011).

Em 1582 na França, a dança clássica começa a estabelecer as concepções estéticas de seus movimentos com primazia na verticalidade do corpo, calcada no conceito de elegância, com gestos disciplinados, rígidos, mas que transparece leveza e delicadeza como poesias. O balé romântico surge explorando a técnica e a virtuosidade do bailarino se equilibrando na ponta dos pés, realizando grandes saltos e giros sem perder o refinamento dos movimentos. Era com esse olhar que os europeus observavam as danças dos negros no Brasil, para assim descreverem a forma como se movimentavam. Enquanto o balé clássico tinha sua dança como premissa de aproximação do céu - onírico -, a dança dos africanos fincava seus pés no chão, no mundo dos ancestrais que por aqui passaram, na força dos elementos da natureza (LIGIÉRO, 2011).

Para Huapaya (2019), a história do teatro ocidental é enraizada com perspectivas burguesas de desqualificação das minorias, com discursos e narrativas pejorativas e exóticas, impondo suas manifestações como de alta cultura numa ideologia de dominação e desprezo do Outro. De modo que o autor propõe os estudos sobre o habitus (encenação da cultura) como caminho para pensar uma montagem e encenação que rompam com os pensamentos exóticos e culturalistas na análise e estudos das artes e das práticas performativas. 
No cinema, na televisão e no teatro, os personagens da mulher, do preto, do índio e do nordestino são formatados segundo essa perspectiva de zoos humanos que surgiu no século XIX. A desumanização e a descontextualização do indivíduo performer se tornaram regras na encenação sobre o povo. Podemos citar, por exemplo, a imagem do africano e do afro-brasileiro, assim como a do preto brasileiro (HUAPAYA, 2019, p. 28-29).

A França, por exemplo, no final do século XIX, teceu uma rede de ideologias racistas, sustentadas por teorias de desigualdade e validadas pelas práticas eugenistas, arquitetando, de tal maneira, um movimento nacional-colonialista que se amparava em projetos que fortaleciam a diferença racial. Esse movimento incluía formadores de opinião da elite francesa, que logo conseguiu se expandir em disciplinas como a etnologia, a geografia e a missiologia. Muitas gerações de franceses foram pedagogicamente orientadas a naturalizar o racismo. Assim, a temática racial ganhou espaço nas culturas de massas por meio das artes, da publicidade e da literatura, criando zoológicos humanos fundamentados numa relação de não reciprocidade com a comunidade negra (MBEMBE, 2018).

As pessoas eram persuadidas de que seria com o sangue branco que se criaria a civilização do futuro. Todos os povos que aceitassem os cruzamentos das raças cairiam em uma desgraça. A salvação estaria na separação absoluta das raças. As multidões negras e amarelas eram prolíficas - acumulando rebanhos que era preciso deportar para algum lugar ou, como alguns mais tarde se esforçariam para implementar, cujos machos deveriam, no limite, ser esterilizados (MBEMBE, 2018, p. 119).

Mbembe (2018) alega que a França de 1920, para fortalecer seu estado colonial, desenvolveu uma lógica racista, embasada em três aspectos: a prática de ocultação e negação; a prática de encobrimento e travestimento e o exotismo, criando, de tal modo, a ideia de degeneração cultural do negro, o esvaziamento e a ocultação, assimilando as condições de vida dos africanos como frívolas e efêmeras, fortalecendo a dialética da distância e da indiferença.

No teatro francês, por volta do século XIX, os negros ganhavam uma atenção especial nas festas mundanas da corte, pois traziam um toque de exotismo e cor ao final dos festejos elegantes. Quando submetidos ao disfarce com trajes orientais, turbantes e plumas, podiam se expressar, mas somente os negros brincalhões e que eram bons dançarinos, mas ainda sim, dentro das concepções que validavam a magnitude do homem branco, conforme os registros encontrados nos pintores da época, como Horgarth, Raynolds, Watteau, Lacrent, Pater, Fragonard e Carmontelle. Os negros eram tolerados na corte, nos salões, na pintura e no teatro, porém sob uma perspectiva racista, descontraída e libertina (MBEMBE, 2018). 
Dentro de uma política racista e displicente, Mbembe (2018) nos apresenta um trecho da trupe de teatro de Josephine Baker durante um ensaio na Paris de 1920. O imaginário exótico da França fez parte dos personagens de Josephine.

Não se compreende a língua deles, nem tentamos reatar o fio das cenas, mas são todas as nossas leituras que desfilam diante da nossa imaginação encantada: romance de aventura, gravuras vistas de relance ou enormes navios engolindo porções de negros carregados com grandes fardos, uma sirene a apitar num porto desconhecido repleto de sacos e de homem de cor, histórias de missionários e de viajante, Stanley, os irmãos Tharaud, Batouala, as danças sagradas, o Sudão, as seminudezes ilustradas da farsa de uma claque, paisagens de plantações, toda melancolia das canções de amas crioulas, toda alma negra com suas convulsões animais, suas alegrias pueris, a tristeza de um passado de servidão, tivemos tudo isso quando ouvimos essa cantora com voz de floresta virgem (MBEMBE, 2018, p. 128).

Filósofos, geógrafos, missionários e escritores franceses desenvolveram obras e peças de teatro; descreviam os hábitos, os costumes e as tradições do continente africano sem nunca colocarem seus pés na África, como diálogos, linguagens justapostas apenas pela força da imaginação e estudos científicos de assuntos que muito pouco sabiam. A partir do século XVIII, floresce, na França, devaneios etnográficos, inesgotável poço de fantasia da representação do povo africano (MBEMBE, 2018).

No século XX, os grupos sociais, que por anos foram colocados como inferiores e desprovidos de capacidade de inovação, iniciam um processo emancipatório de revolta enquanto processo de rebelião consciente, que ressignifica o mundo, rejeitando os extremismos que possam degenerá-la num fim, num fundamentalismo exacerbado e num levante ignorante, pensando, assim, revoluções como atitudes de impulsão contra a opressão (RIBEIRO, 2015).

Os discursos estrangeiros sobre a estética negra das épocas anteriores precisam ser sobrepostos por novos olhares, com os quais o negro deixa de ser refém de uma epistemologia da narrativa branca nas práticas culturais negras, uma reflexão na qual o povo preto precisa engajar-se, sendo autor de sua história e colocando-se diante das emergências de seus discursos, do mesmo modo que se iniciou no Brasil a partir de 1943, com o surgimento dos movimentos políticos. Na linguagem teatral, o Movimento Experimental do Negro (TEN), no Rio de Janeiro/RJ, resgata a cultura de matriz africana, mudando o discurso pejorativo sobre a ancestralidade negra, evidenciando, assim, artistas negros nas artes cênicas (BRAGA, 2015).

A dramaturgia brasileira, na televisão e no cinema, representou, por anos, negros, mulheres, indígenas e nordestinos de maneira exótica e estereotipada, pejorativamente, com roteiro dramatúrgico cristalizado de um olhar eurocêntrico, cabendo aos seus perfis apenas 
funções subalternas. Assim, a televisão trouxe sua contribuição para fortalecer as imagens que propagam a discriminação racial, apresentando modelos de beleza ocidental, enquadrados em visões internacionais de embranquecimento do povo negro e estigmatização do outro, colocando-o como estranho e fortalecendo o conceito de arte e estética burguesas, colonizadoras e fetichistas (HUAPAYA, 2019).

Huapaya (2019) propõe uma reviravolta em que incentiva o processo de pensar a construção corporal do artista em cena a partir do gestus social, um caminho para a estruturação de personagens com sua pesquisa, assentada na valorização do espaço analisado, trazendo as subjetividades que são elaboradas pelo performer - artista em seu processo de montagem e encenação, mas com a delimitação de seu olhar regulamentado pelo grupo pesquisado, uma vez que nas premissas do gestus examina-se com alteridade a camada social e suas práticas performativas, evidenciando os tecidos performáticos e apresentando uma escritura social com narrativas que não sejam exóticas.

A legitimação da arte negra, em especial a dança, está envolta numa rede de memórias coletivas e individuais que precisam estar inseridas na História da Dança Brasileira e afastadas da conotação de espanto. Trazemos em nossa história grandes pesquisadores do corpo na dança negro-brasileira. Precisamos ampliar a mensagem de Mercedes Baptista (1921-2014), Marlene Silva (1936-2020), Clyde Morgan (1940), Eusébio Lobo da Silva (1952), Inaicyra Falcão dos Santos (1958) e Raimundo Bispo dos Santos (1943-2018) - artistas, militantes, manifestantes e propagadores da arte motriz galgada no vasto gestual estético que pesquisa os diversos idiomas negro-africanos. Esses artistas abriram caminhos e juntos construíram um significado que hoje reflete sobre esses temas e reivindica a dança como saber ancestral. A diáspora negra da dança no país está atrelada a um legado de lutas afirmativas, de resistência e de tensões políticas de representação identitária (FERRAZ, 2018).

As atividades que começam a pensar a arte negra - conceitos, posicionamentos, reivindicações, postulados e definições - no processo identitário brasileiro da estética negra nas artes cênicas, são os fóruns artísticos de viés político afirmativo, cujos destaques são os Fórum Nacional de Arte Negra em Salvador/BA e o Festival de Arte Negra - FAN em Belo Horizonte/MG. Eventos, dentre outros, que começam a trazer pensadores que estudam a estética do corpo negro e suas manifestações nas artes cênicas (FERRAZ, 2018). Sobre a Arte Negra Ferraz acrescenta:

$\mathrm{O}$ ato de nomear explica os sentidos que conferimos às nossas experiências. Ao fazê-lo nos localizamos politicamente entre os tensionamentos que disputam as relações de poder e produção de conhecimento histórico sobre a dança. Ao 
propor uma abordagem afirmativa colaboramos com uma visão de mundo que desnaturaliza a norma eurocentrada e colabora na divulgação de referências mais plurais e no reconhecimento das experiências negras que fecundaram a experiência brasileira na dança. Assim sendo, propomos o uso do termo danças negras como conceito definido por fazeres de dança que engendram poéticas políticas complexas, diaspóricas e múltiplas. Enquanto conceito tem um caráter revisionista e provisório que pretende questionar estigmas, equívocos e ocultamentos sobre as experiências negras na dança (FERRAZ, 2018).

Para se pensar uma dramaturgia negra, é imprescindível trazer, apresentar e compreender o gestus social da comunidade pesquisada para que assim se possa falar das relações sociais apontadas nas obras, tecendo e exibindo os modos de vida de um determinado período, sem exotismo ou fundamentalismo, adotando, desse modo, as subjetividades daquela persona, investigando e avaliando a singularização de um pertencimento altivo e respeitoso, que explore os perceptos e afectos de uma montagem performática, atrelada aos conceitos de equidade e alteridade (HUAPAYA, 2019).

Podemos pensar perceptos e afectos como os blocos de sensações na obra, que, entrelaçados, podem dar ao espectador percepções sensíveis, pois compõem afetos que proporcionam experiências estéticas e captam forças, uma vez que o fazer da arte não se trata apenas de reproduzir e criar formas ou, ainda, impressões sensíveis que são erguidas pela manifestação artística em si, mas afetos que se desdobram numa reflexão crítica que indaga os mais diversos signos presentes na obra, associados nas condições de vida, principalmente na relação entre objeto, material, técnica e intencionalidades do criador (KONEL; BARBOSA, 2018).

Pensar questões estéticas de uma obra pode estar mais atrelado à ação intelectual do que a uma estimulação de sentido e ao redirecionamento dos olhares sobre a beleza, a qual se examina as premissas mais amplas no vocabulário estético e questiona a inferência do belo, refletindo, desse modo, sobre os discursos críticos contidos no contexto de facticidade que envolve a obra enquanto arte e as tensões filosóficas que emergem do objeto no ambiente proposto.

Há dois tipos de erros gerados pelo conceito de arte: um filosófico e o outro meramente crítico. O primeiro é interpretar alguma coisa que não é candidata a ser arte, e o segundo consiste em dar interpretação errada ao tipo certo de coisa (Danto, 2014).

As leituras dos objetos são o suporte para a identificação artística, embora a interpretação esteja dentro de uma gama de relativismo e assegure quais partes e propriedades 
do objeto em questão pertencem à obra de arte, significantes que estão introjetados dentro da proposta artística (DANTO, 2014).

\begin{abstract}
A minha teoria não está no espírito da ciência, mas no da filosofia. Se as interpretações são o que constitui as obras, não há obras sem elas, e as obras são malformadas quando a interpretação é errada. E conhecer a interpretação do artista é, de fato, identificar o que ele fez. A interpretação é algo exterior à obra: obra e interpretação surgem juntas na consciência estética. Como a interpretação é inseparável da obra, ela é inseparável do artista, se ela é obra do artista (DANTO, 2014, p. 80).
\end{abstract}

Entender, por exemplo, a gama de complexidade e multiplicidade de informações de como se consolidou a história da população negra no país, é um indicativo para buscar soluções, caminhos e novas abordagens para tratar a arte negra, partindo, nesse aspecto, dos fatos históricos de como se deu o contexto social dessa população brasileira que ainda reverbera na atualidade.

A arte possui sua própria cadeia de multiplicidade para a criação do pensamento, portanto, cabe ao criador artístico desenvolver caminhos para defender uma problemática sem distorcer seus conceitos, evitando, de tal modo, o cenário da distopia. O pesquisador precisa extrair de sua manifestação artística o problema gerador e estabelecer a comunicação de novas sensações artísticas (CARDOSO, 2010).

O hibridismo acaba por ser, na arte contemporânea, uma forte característica. Portanto, a imanência das questões sociais afeta seu processo de compreensão estética, visando a iniciativa de proporcionar ao espectador reflexões críticas e não apenas contemplação relacionada ao conceito de belo - enquanto algo harmônico, hegemônico, organizado e prazeroso - , mas, de outro modo, problematizando questões que afligem a comunidade atual. A arte contemporânea usufrui das informações contidas nos tecidos performativos, tecendo assim um constante processo de questionamentos e fortalecendo as novas concepções estéticas que rompam com ideologias fixadas ou com vieses opressivos (KONEL; BARBOSA, 2018).

Podemos pensar a dança como leitura dos espaços sociais, corpos que interpretam e contextualizam práticas de determinadas camadas da sociedade, expressando símbolos significantes de um modo de vida social - habitus -, trazendo reflexões acerca da ação cultural de seu objeto. A percepção dessa linguagem pode estar atrelada ao gesto, figurino, canto, música, instrumentos, adereço, penteado, à poesia, etc., incorporando a dança e paradigmas sociais como processo de identificação de um tempo sócio-histórico-político social - tradução do gesto em uma temporalidade (OLIVEIRA, 2018). 
Ao falarmos de dança negra, estamos enredados numa cultura negra da diáspora atlântica híbrida, num espaço em que a construção do saber se ocupa de múltiplas subjetividades coletivas, dinâmica de assimilação das diferenças, apropriação e criação de novos gestus sociais. Tudo isso acompanhado de um processo de perda, violência colonial, cruzamentos e recriações gestuais a partir da contingência - facticidade (FERRAZ, 2018).

\section{Descrição, gestus social e encenação}

Pensando a dança contemporânea como linguagem, cuja narrativa corresponde às urgências atuais, restaura comportamentos e apresenta novas abordagens de refletir sobre o gestus social, demarcamos algumas imagens do espetáculo observado, descrevendo as nuances sobre as quais podemos defender a performance como prática performativa através de algumas pesquisas na arte negro-brasileira.

Este espetáculo é um trabalho que o Coletivo Emaranhado tenta executar desde 2016. Com recurso da Secretaria de Estado da Cultura do Espírito Santo Secult/ES no ano de 2019, o grupo concretiza esta montagem que aborda um tema latente que é o feminicídio no Espírito Santo. Trabalho produzido com uma equipe de 16 pessoas, sendo 10 artistas em cena, que também foram intérpretes-criadores. A perspectiva dramatúrgica se respalda nas violações de direitos da mulher, uma pesquisa interseccional entre o racismo e violência de gênero (Relato, Ricardo Reis, Diretor Artístico do Emaranhado, 2020).

Dessa forma, apresentamos alguns signos sobre os quais podemos sinalizar os traços da cultura negro-brasileira, selecionando cinco imagens que serão analisadas com a intenção de demostrar a ancestralidade negra na linguagem corporal proposta, ou seja, um universo estético com base na performance do batucar-cantar-dançar. Portanto, o foco será a análise das artes performativas que possuem o corpo negro como centro de sua manifestação. 


\section{IMAGEM 1:}

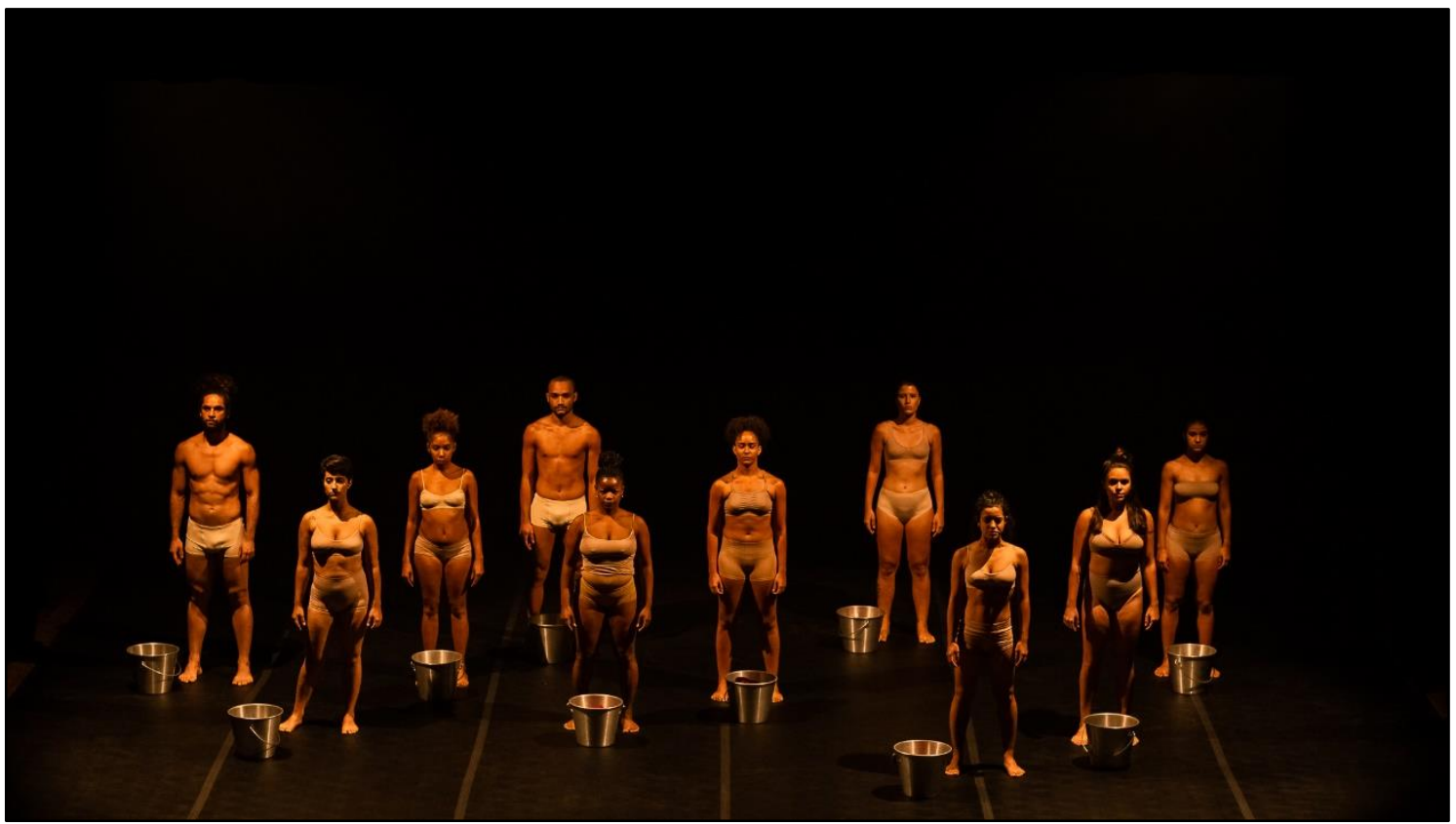

FIRME, Bernardo. Início da encenação, Perfis, Vitória/ES, 2020. Figura 1.

Os corpos se apresentam com suas características biológicas - genótipos e fenótipos suas marcas, registros, desenhos e adornos que lhe são naturais. Brasileiros, aqui tecemos nosso entendimento como povo brasileiro a transversalidade entre as práticas culturais indígenas, africanas e ibéricas, que se expõem para serem vistos dentro de um figurino que realça cada curva, expressividade da face, cabelos e olhos.

Ali, apenas observando os corpos, dentro de um espetáculo que tematiza o feminicídio, o público já pode colocar seus anseios, estereótipos, visões, impressões, que serão reforçados ou rompidos no desenrolar da performance. Quais versões sobre o corpo feminino serão mencionadas? Há dois homens em cena? O figurino, a trilha, os textos cênicos e os gestos desses corpos - que se apresentam enquanto fenótipos - serão modificados?

$\mathrm{O}$ antagonismo maniqueísta, atrelado aos conceitos eurocêntricos de belo, ideal e perfeição, é instigado nessa cena. Os artistas se posicionam seminus para que o espectador note sua pele, seu cabelo, o sexo, as curvas e assimetrias. As mulheres negras são as primeiras a adentrarem a cena, sob os focos de luzes que vão lentamente mostrando seus perfis, um giro no eixo que sempre se encerra com um suspiro fundo e um sorriso apagado. São quatro blackouts, e em cada apagar das luzes entram novos corpos e se repetem a apresentação dos perfis. Do escuro total à luz, assim entravam os artistas em cena e se apresentavam, colocando-se para o 
olhar do observador como um "objeto", mas que demostraria sua potência em torna-se sujeitos no desenrolar da proposta cênica.

Há um padrão estético? Como se afirmam no Brasil a estratificação de cores/raça? O corpo branco é mais belo do que o negro? Há rejeição do cabelo crespo quando relacionado ao cabelo liso? Temos um padrão de beleza que precisa ser alcançado? Quais belezas femininas estão em destaque nas mídias? Os artistas, a cada momento que apresentavam seus perfis, faziam essas perguntas ao público - apenas com sua pré-expressividade.

O ponto de vista discutido na cena é o lugar que esses corpos ocupam atualmente na sociedade, e a importância de se ocupar os espaços e os cargos antes direcionados apenas a um grupo, mas que agora outras comunidades reivindicam. Uma revolta consciente como foi bem apontada por Braga (2015) e Mbembe (2018).

Se pensarmos as noções de corpo como processo sociocultural e que suas concepções são variantes em cada cultura, temos que ajustar nossa reflexão ao contexto histórico do povo negro no Brasil, para então dialogarmos sobre como as concepções de beleza - mídia, televisão, cinema, segmento de cosméticos e moda -, se afirmam na sociedade contemporânea de culto ao corpo.

Foi a partir desse contexto que a direção cênica do espetáculo trouxe a cena para um trabalho que cita as múltiplas violências sofridas pela mulher. Como apontado por Ligiéro, o Brasil, no século XIX, já reunia negros de diversas regiões do continente africano que firmaram suas raízes culturais num processo de criação identitária, no qual coloca o país nesse lugar onde não podemos definir o corpo negro por um viés engessado, como pressupõe o censo demográfico. Assim, a diversidade étnica dos países africanos evidencia a distinção estética brasileira.

É importante ressaltar que autoras como Nilma Lino Gomes (GOMES, 2012) defendem que para problematizar o corpo da mulher negra, podemos tomar como parâmetro o cabelo e o fenótipo como ícone de identidade. O corpo e cabelo da mulher negra no Brasil foram por anos não referenciados como padrão de beleza; as mulheres negras tiveram que passar por um processo de aceitação e ressignificação para serem colocadas socialmente como sujeitos que também são expressões de beleza. O Coletivo Emaranhado, por sua vez, traz em cena a noção de pluralidade, vista de um contexto histórico eugenista por unidade, que foi articulada no Brasil colonial, mas que não deve prevalecer na contemporaneidade, haja vista sua perspectiva de inferiorização do outro. 


\section{IMAGEM 2:}

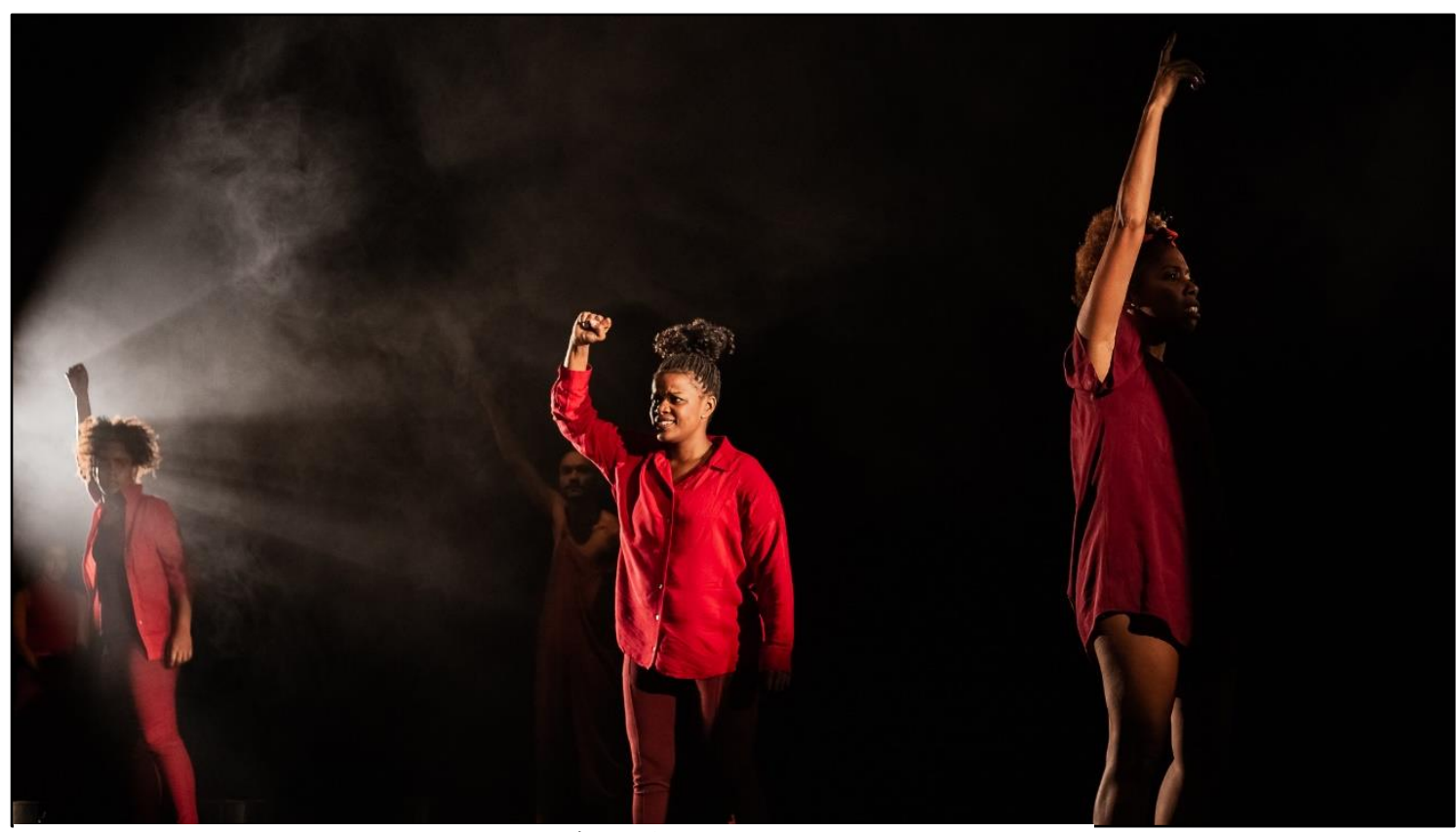

FIRME, Bernardo. Início da encenação, Perfis, Vitória/ES, 2020. Figura 2.

Essa imagem regista a parte final de um texto cênico, interpretado pela artista Léia Rodrigues (ao centro da cena de blusa vermelha). Para uma explanação geral, a artista corporifica a poesia de tatiana nascimento, "Iodo+Now Frágill", cantada também por Luedji Luna $^{4}$. Podemos entender que a interpretação da atriz, somada aos corpos dos bailarinos negros no chão, representa um ato político-performático que provoca o espectador, uma visão de resistência, cujas dores, impostas pelo processo de dominação, ainda estão nos corpos pretos e precisam ser rememoradas para uma reflexão contemporânea.

Tratamos a cena como o início de uma reviravolta dramatúrgica no trabalho que deixa de tocar apenas nas feridas que envolvem as violações de direitos contra as mulheres, tecendo, também, um gestual de fortalecimento e luta de combate à violência contra a mulher, sobretudo as mulheres negras, que são as que mais sofrem de violência doméstica.

A atriz inicia seu texto sinalizando que é/foi mais um corpo negro da diáspora africana. Esse corpo, que surge no fundo do palco, tem fala, um texto potente, de denúncia, que trata as atrocidades sofridas pelos povos de origem africana durante o processo de colonização no solo brasileiro, que até hoje é uma memória dolorosa do processo diaspórico.

\footnotetext{
${ }^{4}$ Álbum Um Corpo no Mundo lançado em 2017.
} 
A força das palavras, unida à interpretação da atriz, eleva a emoção ao raciocínio e reflexão. O momento gera incômodo, pois não é mais possível que o espectador abstenha-se de sua presença desse território brasileiro, o qual todos nós somos responsáveis pelas mundaças epistemológicas contemporâneas. Ocorre um desconforto, pois neste momento o Coletivo Emaranhado nos apresenta uma fala de denúncia, provocando as pessoas que se calam diante do sistema de violência e opressão da comunidade negra.

Os elementos que compuseram a cena foram o texto cênico, as movimentações dos bailarinos no nível baixo e a ausência de trilha sonora, o que proporcionou uma reflexão sobre a formação da história do corpo negro no Brasil, juntamente com toda diversidade que caracteriza nossas manifestações culturais. Tivemos, (in)diretamente, ainda, a transversalidade entre a música, a dança, a literatura, o teatro e a filosofia; e no palco, quatro artistas negros evidenciando a presença de seus corpos, trazendo suas alegações de que na década de 1940 ainda eram marginalizados por sua condição étnica e social. O momento é de uma reverberação histórica do movimento de levante, elaborada pelo Teatro Experimental do Negro (TEM) em 1944, que tem como presença os fortes artistas negros, protagonistas de suas próprias histórias, pessoas pretas falando de um dado social da população negra, sem tornar o tema fetichizado ou exótico ou muito menos um discurso vitimista.

Na poesia interpretada por Leia Rodrigues, sua personagem surge em cena a partir de um suspiro profundo, um fôlego que enche seus pulmões de ar e faz seu corpo se erguer do chão para preencher o vazio sonoro da cena com sua voz. Ao levantar lentamente, limpando seu corpo, como se estivesse se purificando e "autorrealizando um passe", ela articula movimentos com as mãos deslizando-se por seu corpo - dos braços, do encaixe do úmero às pontas dos dedos, e nas pernas, do fêmur aos pés. Movimentos longitudinais, fluidos, distribuídos pelo corpo em direção às extremidades (mãos e pés), sempre de cima para baixo, executados com os braços estendidos naturalmente, com poucas contrações de tronco e com a necessária flexibilidade para a realização do movimento.

Enquanto executava seu gestual, escutavam-se sussurros que foram aumentando gradativamente até ocupar toda a caixa cênica, e como num lapso, o corpo da atriz fica estático, com postura firme, ao centro do palco, os pés descalços, fixos no chão, joelhos semiflexionados, tronco ereto, olhar horizontal, expressão facial firme e um olhar fixo para o público. Seu corpo sinalizava que queria atenção. É neste momento que o público conhece o texto cênico proposto. 


\section{Mas eu já fui trovão que nada desfez \\ Eu ser trovão que nada desfaz \\ Nem o capataz \\ Nem a solidão \\ Nem o estupro coletivo contra sapatão}

Os complexos de contenção: hospício, que é mesma coisa que presídio, que é a mesma coisa que escola, que é a mesma coisa que prisão, que é a mesma coisa que as políticas uterinas de extermínio, que não reconhecem um povo como civilização.

Mas eu sei ser trovão

E se eu sei ser trovão que nada desfez, eu vou ser trovão que nada desfaz

Nem o capataz

Nem a loucura da solidão

Nem o estupro coletivo contra sapatão

Nem a solidão capataz

Queimarem a herança de meus ancestrais

“Arrastaram Cláudia pelo camburão, caveirão, enfim... Esganarem outra Cláudia na região do Itapemirim... Justifica??? Assassinaram Denise da Conceição em Cariacica" (adaptação da atriz).

111 tiros contra 5 corpos pretos

80 tiros de fuzil contra um carro branco

"Executarem Marielle Franco" (adaptação da atriz).

Epahey Oyá!

Eu sei ser trovão que nada desfez? Sim, Eu sei ser trovão...

E nada, nada, nada me desfaz.

(tatiana nascimento. Poesia Iodo+Now Frágil. 2017).

Os bailarinos, no chão, reagiam às denúncias expostas nas intenções do texto, movimentando-se num elevar e cair de corpos e braços, rolando pelo chão como numa luta para a reconstrução e visibilidade de sua história negra. Os movimentos se intensificam, expandem; a fala também acompanha a emoção do texto quando ganha exaustão, e o choro aparece, estimulado pela narrativa.

Ao final da cena, da exposição desse texto, temos a fotografia supracitada. A atriz conduziu, por meio de sua entonação vocal, gestos firmes dos braços e expressão facial - que se emocionavam ao tecer dados políticos, sociais e raciais sobre a população negra no Brasil , uma manifestação de fortalecimento das mulheres negras. No texto, com licença poética, ela apresentou os dados e os casos de feminicídio no Espírito Santo, fatos reais que deixaram a cena densa, forte e apreensiva.

O grito para o orixá feminino Iansã, saudando essa divindade afro-brasileira, ecoa por todo o teatro como sinônimo de luta e resistência da manifestação negra no país. Um gesto de fortalecimento da diáspora africana.

$\mathrm{Na}$ cena, temos uma performance política emancipatória da população negra, corporificada pela atriz e seus bailarinos, que iam executando movimentos de espasmos e contrações, enquanto escutavam os dados, estáticos, sobre a morte e degeneração desse povo. 
Temos artistas negros tecendo informações sobre o corpo negro, uma ação que Braga (2015) defende como necessária para mudar os conceitos estéticos da arte no Brasil, colocando os negros como engajadores de sua memória ancestral.

A linguagem adotada se referencia nas técnicas do teatro; a percepção estética do fenômeno artístico conquista sua significação por meio do impacto inicial da poesia, que transita entre o ficcional e os relatos reais da sociedade brasileira. $\mathrm{O}$ jogo e o olhar da atriz estavam ancorados na realidade social, mas, por outro lado, o espectador foi capaz de perceber a poesia no palco. Em toda a cena, o corpo de Léia Rodrigues estava vibrante, energético, magnético, a voz segura ao falar cada palavra, impostação vocal firme; seu gestus era de força, mas também de revolta, uma revolução consciente.

Seu movimento corporal era de uma mulher contemporânea, com gestos familiares, mas com potência de afetar e causar estranheza, estabelecendo, como proposto por Bertolt Brecht, um distanciamento crítico da cena. Os elementos plásticos e temporais nos apresentaram uma verossimilhança com a realidade, um contato com a realidade tal como ela é, tornando o tema, como o feminicídio, próximo, relacional, social, uma leitura estética na qual a mulher negra é uma das principais vítimas. A cena propõe aos espectadores posturas de reflexão e alteridade, reforçando, assim, a confirmação de que o alvo não muda e que os corpos atingidos pelas balas de revólveres e chibatas estão intimamente ligados à falta de seguraça e reconhecimento dos direitos civis do povo negro.

\section{IMAGEM 3:}




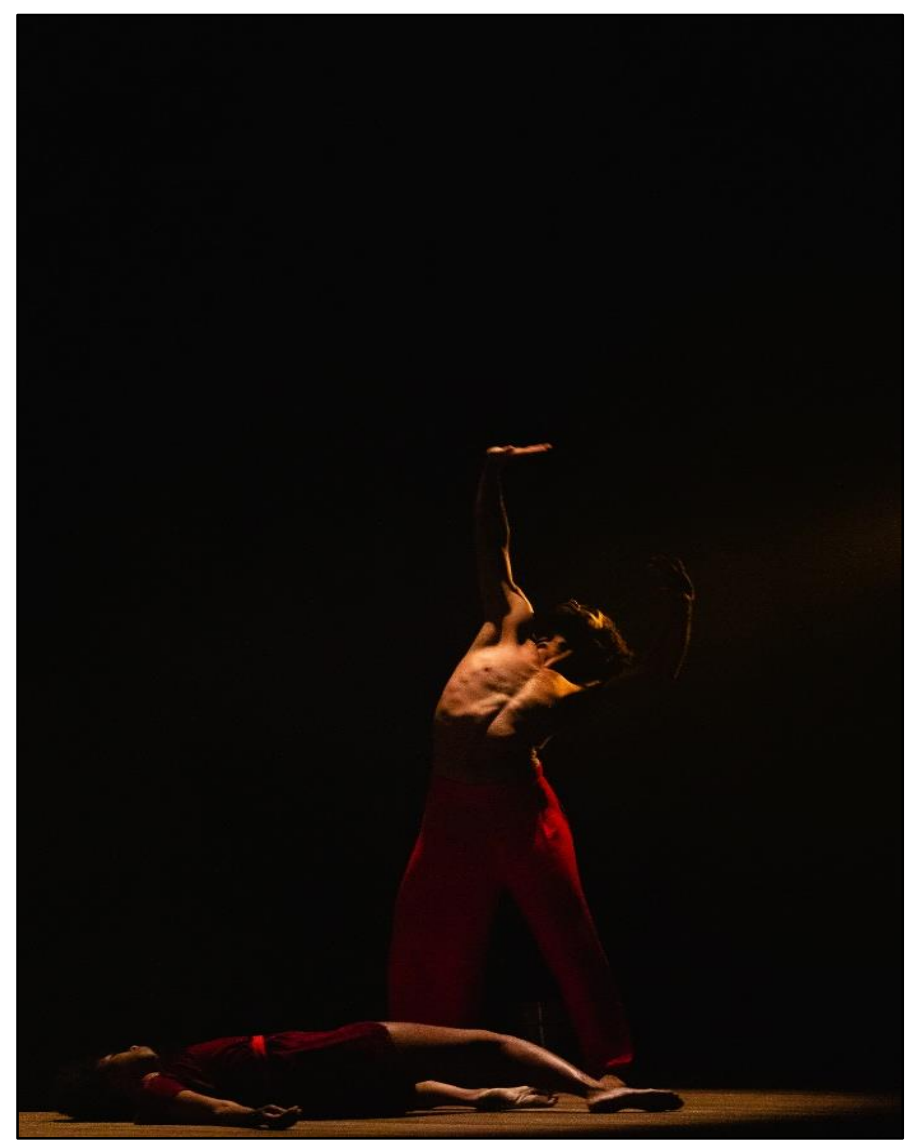

FIRME, Bernardo. Dança de Iansãa. Vitória/ES, 2020. Figura 3.

Essa cena é uma passagem do bailarino, entre uma coxia e outra, cruzando o palco numa diagonal (entrada na direita baixa e saída na esquerda alta). A performance acontece entre os corpos estáticos das pessoas pretas no chão. Nesse cenário, ao som da música “Oriki, Orixá Exu" 5, o performer entra com imponência, corpo dilatado e vigor, com os braços, que inicialmente simbolizam o irukerê - espada de cobre -, manipulando o ar. O corpo ganha tremulações, ondulações do tronco, proximidade do chão e velocidade.

O corpo do artista entra no palco alinhado, a simetria da bacia sobre os pés, o tronco sobre a bacia e a cabeça sobre o tronco, com a coluna em ascensão, trazendo uma corporeidade de poder, coragem e serenidade, e os movimentos de tremulação mudando tal gestualidade. A postura vertical humana e as premissas desse corpo ereto se diluem pelos movimentos das virilhas, que desalinham o posicionamento dos ilíacos e fêmures. O peso da massa corporal é solto pelo solo, encontrando movimentos de locomoção quadrúpede e bípede, gradativamente;

\footnotetext{
${ }^{5}$ Canção interpretada por Felix Omidiré e Grupo Ofa do Álbum Obatalá, uma Homenagem à Mãe Carmen, ano 2019.
} 
e as oscilações entre o corpo vertical e horizontal apresentam signos da capoeira, danças dos orixás e poéticas individuais de uma dança contemporânea.

Os arquétipos de Iansã estavam presentes num corpo masculino, que reverberava sensualidade, força e axé. A relação entre os gestos, os atabaques e o modo como se ocupou a cena é o que Huapaya (2019) denominaria como corpo-existência-ação-performance que se assenta nas manifestações dos candomblés. A identidade corpóreo-gestual em cena uniu ritmo, gestus social e uma movimentação corporal como índice de preservação de uma cultura negra que está em constante ocupação, já que nos deparamos com um contexto histórico brasileiro de hegemonia caucasiana ocidental. A cena trouxe o batucar-cantar-dançar como epistemologia do povo negro-brasileiro.

Os signos da capoeira e da dança dos Orixás compuseram o repertório dessa ação, que registra a história do corpo negro no Brasil, demarcações de combate, resistência e ponderação sobre o corpo contemporâneo no mundo, um território que mapeia a cultura negra.

\section{IMAGEM 4:}

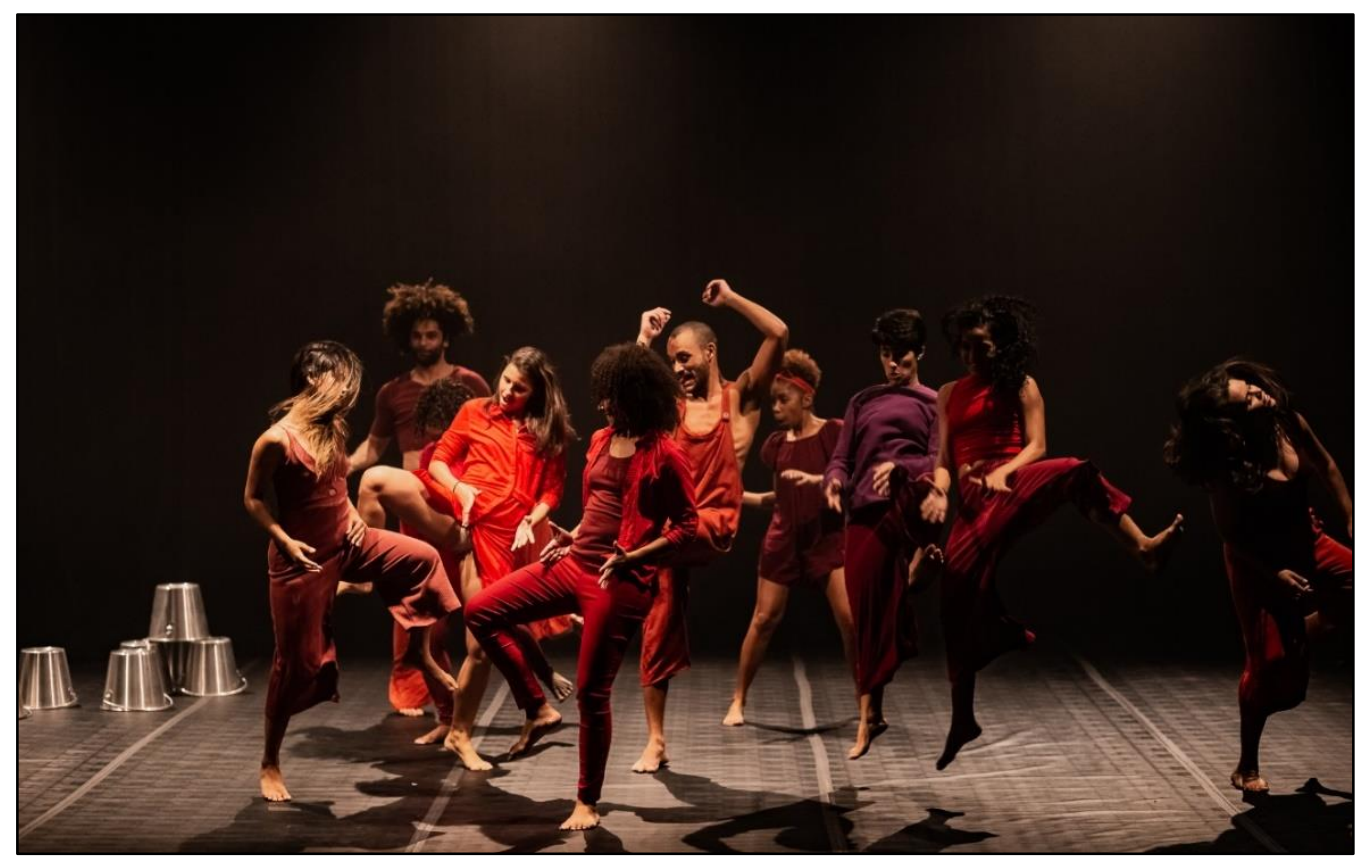

FIRME, Bernardo. Funk. Vitória/ES. 2020. Figura 4.

A coreografia é um convite para que se rompa com todas as amarras que aprisionam os corpos que lutam por liberdade. A música é o Funk, gênero musical que se iniciou no Soul Music dos negros estadunidenses no final da década de 50. A cena une o funk carioca e as políticas de ações afirmativas do gestus social das comunidades negras da periferia. A canção 
"Revolucionou" da artista carioca Patrícia Ilus, que reside no Espírito Santo, é um manifesto de fortalecimento da mulher. O Coletivo Emaranhado, ao coreografá-la, fortalece e expande o trabalho da artista, que é engajada em posicionamentos de combate à violência contra a mulher. Segue abaixo a canção:

\section{REVOLUCIONOU}

Olha só como ela anda

Na batida a gente vê

A cabeça ela levanta

Ninguém sabe o porquê

Ela não é mais santa

Salomé, Calcutá

Não há nada que lhe digam

E que faça ela parar

Revolucionou...

O corpo é meu você não tem que opinar Nenhuma roupa te autoriza a me tocar $(2 \mathrm{x})$

Revolucionou...

O seu pudor é uma maneira de oprimir

Eu sou mulher e me impediram de falar

O corpo é meu você vai ter que admitir

Se não quiser como um trator eu vou passar

Revolucionou...

A minha voz silenciou

Me convenceram que eu tinha que ceder

A minha história ninguém contou

Pra mim já chega agora eu digo: A mulher revolucionou

Pode me xingar você não vai me humilhar

Pois já não me importa em seus padrões me encaixar

E não adianta me ridicularizar

Vim pra ocupar, arreda o pé, vamos entrar

Revolucionou ...

A mulher revolucionou

A preta revolucionou

A branca revolucionou

A trans revolucionou

A pobre revolucionou

A rica revolucionou

(Revolucionou. Letra e Música: Patrícia Eugênio, 2019). 
A dança surge em cena como manifesto, mas também com muita diversão. Os artistas, sorrindo e abusando do gestual individual, expõem suas formas de se movimentarem dentro desse ritmo negro e brasileiro, que rememoram o cotidiano das favelas, comunidades e bailes funks (popularizados no Brasil a partir dos anos 70). O compasso se desvela no espetáculo com força e resistência, e os corpos são coreografados com os movimentos que resgatam a África, usando os quadris e os saltos impulsionados pelo ritmo do tambor.

Há na cena um grito das mulheres, com ocupação e presença cênica na intenção de tomada de poder; os corpos dos artistas se dilatam, ficam expansivos e restauram comportamentos do cotidiano de uma mulher, como os gestos de maquiar, caminhar, embelezar-se e (des)pentear; e também atitudes como bate-cabelo e movimentos característicos do funk, como passinho, quadradinho, agachado e rebolado.

A cena foi um grande baile; nas danças, os movimentos executados tiveram os joelhos flexionados, swing de quadril, o uso exacerbado dos glúteos descendo até o chão, as pernas afastadas, que abrem e fecham com as mãos nos joelhos, sempre se valendo do rebolado do quadril e movimentos pélvicos repetidos até a exaustão.

Esteticamente, pode-se caracterizar o passinho como a sofisticação do sampler, da colagem, representada na corporalidade. Essa afirmação se deve à apropriação feita pelo passinho de elementos de diversas outras danças, como Frevo, Break, Street Dance, Trap Dance, Samba, Kuduro, entre muitas outras, - além de contar com a criatividade, elementos da teatralidade e os traços pessoais do criador/executor/dançarino - resultando em um produto final único. Isso faz com que o passinho, através da apropriação tanto de danças regionais quanto de passos de danças conhecidas e difundidas mundialmente, se torne uma representação híbrida, em que o global e o local se misturam e se complementam. [...] Ora, a dança passinho, em todas as suas peculiaridades próprias da periferia brasileira e semelhanças com outras manifestações principalmente as negras - de outros países, realizada por sujeitos sociais jovens, pobres e negros em sua maioria, é, para esses jovens, instrumento de ascensão social - seja para os que sonham em adentrar a grande mídia e viver da dança, seja para os que usam a dança como ferramenta de sociabilidade e de sobrevivência dentro da própria comunidade (NASCIMENTO, 2015, p. 5).

O objetivo da cena era um levante para unir mulheres pretas, brancas, cis, trans, pobres e ricas numa única luta que é a de igualdade de gênero. Imersos estavam os movimentos cotidianos dos povos negros diaspóricos, reações de uma vida cotidiana negro-brasileira, valores simbólicos de uma linguagem da periferia de colocar-se no tempo e espaço para recriar referenciais estéticos de gestos, movimentos e formas de comunicação preta. 


\section{IMAGEM 5:}

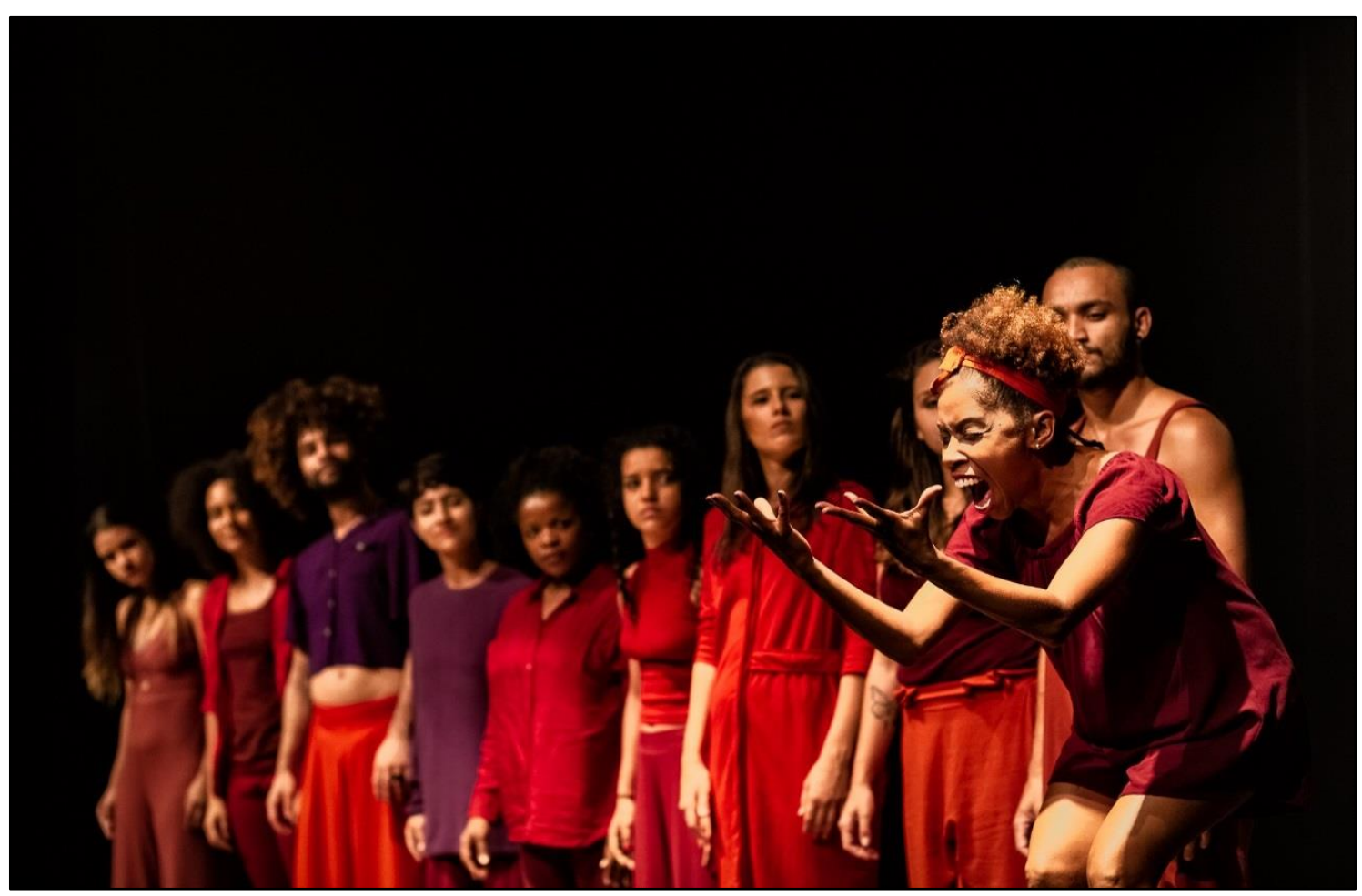

FIRME, Bernardo. Elza Soares. Vitória/ES. 2020. Figura 5.

Esta cena se inicia com um convite. Ao sair de um encontro de aconchego, abraço coletivo, cuja trilha era o som dos batimentos cardíacos de um bebê em uma ultrasonografia útero -, a atriz sai desse contato corpóreo e apresenta uma fala motivadora. Na frente do palco, diz para todas e todos que podemos sonhar com novos futuros para as mulheres e que esse desejo é coletivo.

Impreterivelmente, o dispositivo dessa encenação é a interpretação da atriz Elaine Vieira, que canta e interpreta a música "Língua Solta", interpretada por Elza Soares - no álbum Deus é Mulher -, artista, cantora de grande nome da música popular brasileira, que enfrentou racimo e preconceito por sua origem humilde; mulher preta, periférica, que teve seu primeiro filho aos 12 anos de idade e aprendeu a ouvir sua poderosa voz ao subir o morro com uma lata de água na cabeça, passando por cima de várias dificuldades até se estabelecer em seu ofício.

Neste momento, o espetáculo caminha para o seu encerramento com os artistas se colocando lado a lado, criando um altar com seus elementos cênicos - baldes perfilados - que viram passarela por onde a atriz sobe e passa, cantando o desafio de atravessar o caminho acima das desilgualdades. 
É dia de falar e de ouvir, também

Com medo de careta, dou a mão

E cala o horror, a cara feia, noite escura

Que a coragem é língua solta e solução

É dia de encarar o tempo e os leões

Se tudo é perigoso, solta o ar

Escuta a maré, a lua, o rádio, a previsão

Por nós, só nós, e o mundo inteiro pra gritar

Por nós, só nós, e o mundo inteiro pra gritar

Por nós, só nós, e o mundo inteiro pra gritar

(Trecho. Língua Solta. Letra: Alice Coutinho. Interpretação: Elza Soares, 2018).

Nesse caminho, o corpo da atriz emana energia e vibração, e sobre o último balde, ela conclui com o verso "por nós, só nós e o mundo inteiro para gritar". Cada integrante a observa com seus olhares de incentivo e parceria, concordando que todo dia é "dia de falar e de ouvir também". Seu corpo ocupa a cena, com sinal de atenção, convocando todas as mulheres para lutarem e combaterem a violência estrutural contra a mulher, em especial as mulheres negras.

O corpo da performer extravasa expressividade, um canto/interpretação cercado de simbologias de fortalecimento das mulheres, sobretudo as pretas. Atitudes de segurança, de motivação, empolgação, acalanto e alteridade resplandecem no corpo da atriz e de todos os artistas em cena que se sentiram convidados a lutarem juntos. A interpretação da canção de Elza Soares foi um convite para que nenhuma mulher se cale, chamando todas à sororidade feminina.

\section{Conclusão}

Qual a força que tenho para me manter de pé? A do meu corpo coberto de sal? A da travessia do Atlântico? Que os ventos de Iansã se dissipem para comunicar sobre a arte negrobrasileira. Corpos negros importam. Corpos negros que foram ameaçados, agredidos, violados, retirados de seu território - arrancados do continente africano -, trazidos dentro dos navios negreiros, e que até hoje, século XXI, precisam resistir.

Fundamentado em dados sobre os índices de violência contra a mulher, o Coletivo Emaranhado propõe uma criação colaborativa para denunciar uma cultura de violência de gênero que perpassa pelas ações sutis do cotidiano até chegar às situações mais drásticas, como, por exemplo, os inúmeros casos de feminicídio. Essas linguagens se atravessam, também, criando um manifesto, cuja reflexão se dá acerca da necessidade e urgência dessas ações e posicionamentos serem revistos.

O espetáculo é uma proposta concreta em favor das mulheres, principalmente das mulheres negras, e apesar do elenco não ser composto apenas por pessoas negras, o corpo de 
artistas é um signo do saber, produzido e memorizado na relação ontológica do cotidiano negro afrodiaspórico. A pré-expressividade é de mulheres fortes, poderosas e seguras.

Os textos cênicos, as músicas cantadas pelos artistas, o jogo de linguagem com os fenótipos e o protagonismo das mulheres pretas em cena promovem e reivindicam os direitos da população negra.

Em alguns trechos, as referências da cultura negro-brasileira reverberam na corporeidade dos artistas, tais como na música da cantora Luedji Luna somada à poesia de tatiana nascimento, "Iodo+Now Frágil"; na canção "Língua Solta" de Alice Coutinho, interpretada por Elza Soares; na música “Oriki, Orixá Exú” interpretada por Felix Omidiré e Grupo Ofá; a presença do funk "Revolucionou" de Patricia Ilus, e as menções à música “Amar(elo)", releitura do cantor Emicida com a participação de Majur e de Pablo Vittar nos textos que emanam saudações afro-brasileiras e nomes de mulheres negras que são ícones da história social brasileira, além das tentativas de se trazer para a cena a sensibilidade de trabalhar essa temática sem negligenciar outros temas que englobam o feminino e as mulheres.

O direito à igualdade e não discriminação, que são princípios fundamentais dos direitos humanos, também foram apontados no espetáculo como luta contra qualquer distinção dos direitos das pessoas, não com base no fato de elas serem lésbicas, gays, bissexuais ou transgêneros, ou ainda, como é ilegal fazê-lo, baseado na cor da pele, raça, sexo, religião ou qualquer outra condição.

Destacamos também que os artistas representam pelos gestos e figurinos o arquétipo de Iansã. As roupas em tons marrom e vermelho compõem a estética das cenas, um bailado que remete ao ar, tentativa de manipulação dos ventos com as mãos, com os movimentos rápidos e assimétricos.

Realizando essa montagem, o Coletivo Emaranhado reforça seu interesse por criações atentas às questões sociais, apostando na arte como ferramenta reflexiva de atravessamento do pensamento crítico como colaborador de uma mudança de mundo. Podemos acreditar que a ideologia do Emaranhado é provocar a efervescência da arte negra no Espírito Santo, assim como todo movimento político e social amparado no propósito de defender as culturas afrobrasileiras e seus ideais através da dança. A música, os movimentos e os sentimentos de pertencimento da cultura negra precisam ecoar contra o racismo e o pré-conceito racial, fortalecendo-se como um coletivo de arte cênica que serve de espaço e caminho para que artistas negros possam enfrentar o racismo conjectural histórico. 


\section{REFERÊNCIAS BIBLIOGRÁFICAS}

BRAGA, Amanda Batista. História da beleza negra no Brasil: discursos, corpos e práticas. São Carlos: EdUFSCar, 2015.

CARDOSO, JR, H. R. Arte e Filosofia como Disciplinas das Multiplicidades: problema filosóficos e problemas estéticos em interferência intrínseca, segundo Deleuze. UFOP, Revista ARTEFILOSOFIA, v. 1, 2010.

COUTINHO, Alice. Intérprete: Elza Soares. Compositora: Alice Coutinho. Canção: Língua Solta. In: Deus é Mulher. São Paulo: DeckDisc, 2018. Disco, faixa 5 (5 min 27s).

DANTO, Arthur C. O descredenciamento filosófico da arte. Belo Horizonte: Autêntica Editora, 2014.

DUH, Dj; EMICIDA; VASSÃO, Felipe. Intérprete: Emicida, Majur, Pablo Vittar. Compositores: DJ Duh, Emicida e Felipe Vassão. Canção: AmarElo (Sample: Sujeito de Sorte - Belchior). In: AmarElo. São Paulo: Sony Music Entertainment, 2019. Disco, faixa 10 (5 min 21s).

DUSSEL, Enrique. Filosofia da libertação na América Latina. São Paulo: Co-Edição Edição Loyola, 1977.

FERRAZ, F. M. C. Danças negras: historiografias e memórias de futuro. São Paulo: Sesc Nacional, 2018.

FIRME, Bernardo. Abajur Cor de Carne - Cartografia pela Dança, Vitória-ES 2020. 05 Fotografias. $500 \quad$ x 500 pixels. Disponível em: https://www.flickr.com/photos/137046045@N08/albums/72157710883246138. Acesso em 21 jun. 2020.

GOMES, N. L. Corpo e cabelo como símbolos da identidade negra. Revista Ação Educativa. São Paulo, 2012.

HUAPAYA, Cesar Augusto Amaro. Encenação do gestus social: personas, personagens e corpus em vidas. Editora: Grupo de Teatro Experimental Capixaba - GTEC e Curio, Vitória/ES, 2019.

ILUS, Patricia. Intérprete: Patricia Ilus. Compositora: Patricia Ilus. Canção: Revolucionou. In: Single 2018, Patricia Ilus. Vitória: Mfive, 2018. Single (3 min 30s).

KONELL, V.; BARBOSA, A. C. A. Percepções Sensíveis na Arte Contemporânea: concepção estética de Gilles Deleuze e Félix Guattarri. Revista ART\&SENSORIUM, v. 5, 2018.

LIGIÉRO, Zeca. Corpo a corpo: estudo das performances brasileiras. Rio de Janeiro: Garamond, 2011.

MBEMBE, Achille. Crítica da razão negra. São Paulo: n-1 edições, 2018.

NASCIMENTO, L. M. P. O passinho como cultura híbrida nas paisagens transculturais urbanas. In: XXXVIII Congresso Brasileiro de Ciências da Comunicação - INTERCOM. Rio de Janeiro: Intercom, 2015, v. 37. 
NASCIMENTO, tatiana. Intérprete: Luedji Luna. Compositora: tatiana nascimento. Canção: Iodo+Now Frágil. In: Um Corpo no Mundo. São Paulo: YB Music, 2017. Disco, faixa 11 (4 $\min 50 \mathrm{~s})$.

OLIVEIRA, Nadir Nobrega. Expressividades corporais autônomas. In: Congresso ABRACE, 2008, Belo Horizonte. Congresso IV ABRACE, 2008, p. 3.

PASSOS, Iuri; BARAÚNA, Luciana; ASOGBÁ, Yomar. Intérprete: Felix Omidiré e Grupo Ofa. Compositores: Iuri Passos, Luciana Baraúna e Yomar Asogbá. Canção: Oriki - Orixá Exú. In: Obatalá - Uma Homenagem à Mãe Carmen. Salvador: Deck, 2019. Disco, faixa 1 (1 min $57 \mathrm{~s})$.

RIBEIRO, Rafael Lins. Albert Camus e a questão essencial: absurdo e revolta. 2. Ed/Yuri Miguel Macedo (Org). Porto Seguro: Editora Oyá, 2019. 